\title{
Üniversite Öğrencilerinin Sahip Olduğu Değerler Psikolojik İyi Oluş Ve Mutluluk Düzeyleri Arasındaki Yordayıcı İlişkiler ${ }^{1}$
}

DOI: $10.26466 /$ opus. 472450

\begin{abstract}
Semra Bulut ${ }^{*}$ - Bülent Dilmaç
*Uzman, İstanbul Büyükşehir Belediyesi,Meslek Edindirme Kursları İstanbul / Türkiye E-Posta: bulut-semra@hotmail.com ORCID: 0000-0002-6324-5166

${ }^{* *}$ Prof. Dr., Necmettin Erbakan Üniversitesi, Eğitim Fakültesi, Meram/ Konya/ Türkiye E-Posta: bulentdilmac@gmail.com

ORCID: $\underline{0000-0001-5753-9355}$
\end{abstract}

$\ddot{O} z$

Araştırmanın amacl, üniversite öğrencilerinin sahip olduklarn değerler, psikolojik iyi oluş ve mutluluk düzeyleri arasındaki ilişkilerin incelenmesidir. Araştırmada değerler, psikolojik iyi oluş ve mutluluk değişkenleri arasındaki ilişkinin sınanması amacıyla yapısal eşitlik modellemesi analizi yapılmıştır. Yapısal eşitlik modellemesi analizi AMOS 19 Programı ile gerçekleştirilmiştir. Araştırmanın çalışma grubunu 2016-2017 yılı içerisinde İstanbul ilinin çeşitli üniversitelerinde, öğrenim gören 747 öğrenci oluşturmaktadır. Araştırmada gerekli verilerin toplanması için, Kişisel Bilgi Formu, 'Değerler Ölçeği', 'Oxsford Mutluluk Ölçeği' ve 'Psikolojik Iyi Oluş Ölçeği' kullanılmıştır. Ayrıca toplanan verilerin yüzde ve frekans hesapları SPSS 18 paket programı ile gerçekleştirilmiştir. Araştırmadan elde edilen bulgulara göre, değerler ölçeğinin alt boyutlarn ile psikolojik iyi oluşölçeği arasinda pozitif yönlü anlamlı ilişki bulunmuştur. Ayrıca test edilen modelde, üniversite öğrencilerinin mutluluk düzeylerini etkileyen ikinci önemli bağımsız değişkenin değer olduğu bilgisine ulaşılmıştır. Ulaşılan bulgular ışı̆̆ında çalışmanın öneriler kısmı geliştirilmiştir.

Anahtar Kelimeler: Değerler, Psikolojik İyi Oluş, Mutluluk

\footnotetext{
${ }^{1}$ Bu çalışma Semra BULUT tarafindan Prof. Dr. Bülent DiLMAÇ denetiminde yürütülmüş olan "Üniversite Öğrencilerinin Sahip Olduğu Değerler Psikolojik Iyi Oluş Ve Mutluluk Düzeyleri Arasındaki Yordayıcı Ilişkiler" başlıklı yüksek lisans tezinden üretilmiştir.
}

OPUS @ C Uluslararası Toplum Araştırmaları Dergisi-International Journal of Society Researches ISSN:2528-9527 E-ISSN : 2528-9535

http://opusjournal.net 


\title{
Predictive Relationships Between University Students' Values, Psychological Well-Being And Happiness Levels
}

\begin{abstract}
The purpose of the research is to survey the relationships psychological well-being, happiness grades and the values which university students have. Structural equation modelling analysis is applied to test the relationships between values, pschological well-being and happiness variables in this research. Structural equation modelling analysis is carried through with AMOS 19 program. The study group of the research is consisted of 747 students from various universities of Istanbul in the year of between 2016-2017. Personal information form, Dilmac, Aricak and Cesur (2014) ValuesScale, Oxford Happiness Scale and Psychological Wellbeing Scale were used to collect necessary data in the research. Percentage and frequency calculations of collected data were also performed with the SPSS 18 packet program. According to the findings which are obtained from the research there is an affirmative significant correlation between subscales of thescale of values and psyhological well being scale. Inaddition to that, it is discovered that these condmajorin dependent variable which in fluences the happiness grade of university students is the "value" term in the tested model. With the light of obtained findings, suggestions part has been discovered.
\end{abstract}

Keywords: Values ,PsychologicalWell- Being, Happiness

OPUS (c) Uluslararası Toplum Araştırmaları Dergisi-International Journal of Society Researches ISSN:2528-9527 E-ISSN : 2528-9535

http://opusjournal.net 


\section{Giriş}

İnsanı tanımak, tabiatını, varoluş yapısını anlayabilmek ve bu yapının işlevlerini ve potansiyellerini görebilmek onun, alemdeki yerini ve bu alemle olan ilişkisini bilmekle mümkündür (Bircan, 2001). Bir bireyi herhangi bir durum karşısında harekete geçiren veya harekete geçmesini engelleyen sebep nedir? Bir eylemin veya eylemsizliğin bağlı olduğu inanç kaynağını nereden almaktadır? Çeşitli alternatifler içerisinde bir durumu diğerine tercih etmenin altında hangi amaç yatmaktadır? Bu bakımdan ele alındığında değerler bireyi birçok yönüyle ortaya koymaktadır. Çünkü değerler bireyin duygu, düşünce ve davranış boyutlarıyla bir ilişki içerisindedir (Dilmaç, Bozgeyikli ve Çıkıllı, 2008). Zihinsel süreçte algıların, duygusal bakımdan hislerin ve bir fikir ortaya koymanın temelinde inanç vardır ve değerler bu inancı karşılamaktadır. (Güngör, 1998). Çünkü değerler bir şeyin arzu edildiğini veya arzu edilmediğini ortaya koyan inançlardır (Dilmaç, 2007).

Psikolojik açıdan değerler, bireyin kişiliğini ortaya koyan motivasyonların temelini oluşturmaktadır. Psikologlar, değerleri gelişim süreci içinde erken yaşlarda kazanılarak davranışlarda kendini ortaya koyan tercihler, şeklinde tanımlamaktadır (Sağnak, 2004).

Değerler, insanın önemli görüp ulaşmak istediği ve peşinden koştuğu şeylerdir. Ayrıca insanı kötü davranıştan alıkoyan ideallerdir. Bu idealler toplumdaki bireylere etki ederek yayılımı sağlar ve bir araya toplanmasında öncülük eder (Bolay, 2007). Değerler, bireyin sergilediği davranışları içinde bulunduğu toplumun faydasına göre düzenleyip, iyi ve doğruya yönelik düşünce ve davranış geliştirmesinde ölçek niteliği taşıyan olgulardır (Bozgeyikli, Derin ve Toprak, 2016; Kapkın, Çalışkan ve Sağlam, 2018). Schwartz (2012), değerleri, önem ve hiyerarşi atfıyla açılamıştır. Değerler insana kendisi için neyin önemli, neyin önemsiz olduğunu belirleyen ölçütlerdir ve bunların önemlilik derecesinin, kişiden kişiye veya gruptan gruba değişiklik gösterebildiği yorumuna yer vermektedir. Fchter'in (1990) getirdiği sosyolojik değerlendirme ise değerlerin, kişiye ve gruba faydası olan şeyler olduğu yönündedir. Değerlerin bireyi çevreleyen bütün olgularla ilişkisi vardır. İnançları, normları, tutum ve kültürü etkilemekle kalmayıp, oluşumuna da kaynak olmaktadır. Bir kültürden bahsederken çoğunlukla değerler referans alınarak tasvir edilişinin temel 
sebebi de bu özelliğinden kaynaklanmaktadır (Özensel, 2003). Değerlerle ilgili tanımlamalar incelendiğinde, örf, adet, inanç, amaç, ilke, obje, insan ve fikirler hakkında kanaat belirtmede kullanılan ölçü ve yöntem hükmünü içeren her türlü yargıların ön plana çıktığı görülmektedir (Keskin, 2016). Bu sebeple değerler, felsefe sosyoloji ve psikoloji gibi birçok bilimin ele alıp üzerinde yoğun çalışmalar yapıldığ 1 konulardan biri olmuştur (Bircan ve Dilmaç, 2015).

Değerlerle ilgili olarak çeşitli sınıflandırma çalışmaları yapılmıştır. Ülkemizde yapılan çalışmalardan biri Güngör'ün (1998) yapmış olduğu çalışmadır ve değerleri yedi alanda sınıflandırarak yirmi dokuz değer ifadesi ortaya koymuştur. Bu yedi değer alanı, "estetik, ahlaki, teorik/ilmi, iktisadi, dini, siyasi ve sosyal" değerlerdir. Her değer alanı kendi sahasına yönelik değerlerle ilgili olmakla beraber, diğer değer alanlarıyla da ilişkilidir. Yani iktisadi bir değer, kendi alanı dışındaki değerlerle bağlantı halindedir. Bir diğer çalışma ise Dilmaç, Arıcak ve Cesur'un (2014) değer s1nıflandırmasıdır ve akademik literatürde dokuz boyutla yer almaktadır. Bu siniflandırmanın alt boyutlarını;

- Toplumsal Değerler(Social Values): Yardımseverlik, tevazu (alçak gönüllülük), toplumsal huzur, nezaket, saygı, yaşam hakkı, sorumluluk, tutarlılık, hoşgörü, öz disiplin.

- Kariyer Değerleri (CareerValues): Kalite, kariyer, itibar/saygınlık, eğitim, diş disiplin

- Entelektüel Değerler (Intellectual Values): Beden sağlı̆̆1, akıl/ruh sağlığı, bilgi, çalışma, başarı, kişisel gelişim.

- Maneviyat (Spritual Values): İbadet, din/iman, inanç/ideoloji ve iç huzur.

- Materyalistik Değerler (Materialistic Values): Para, mal/mülk ve statü

- Insan Onuru (Honor of Humanity): Namus, şeref/onur ve adalet (hakkaniyet)

- Romantik Değerler (Romantic Values): Aşk, eş/sevgili ve haz/zevk

- Özgürlük (freedom): Özgürlük/bağımsızlık, kültür ve emek

- Fütüvvet (futuwwat/munificencecourace): Cömertlik ve cesaret değerleri oluşturmaktadır. 
Değerler tek başına bir kategori oluşturmazlar ve aralarında uyum içeren bir ilişki vardır (Güngör, 1998). Ayrıca bulunduğu toplumu bir arada tutacak standartlar sağlama, kültürel kodlar oluşturma, davranışlara belli önem sırası atfetme ve normlar aracılığıyla düzeni sağlama gibi olumlu toplumsal işlevleri vardır. Bireysel anlamda ise yol ve yöntem sunarak doğru davranış kalıplarıyla, bulunduğu sosyal sisteme uyumu sağlamaktadır (Keskin, 2016). Fichter (1990), değerlerin genel işlevlerine ek olarak, bireylerin ve grupların sosyal değerlerini yargılamada araç olma, toplumda dayanışmayı sağlama ve belli bir rol seçtikten sonra bireylerin bu rolün gerektirdiği davranışı sergilemesinde rehber olduğunu belirtmektedir.

İslami felsefede değerler erdemler bağlamıyla açıklanmış ve mutluluk kavramıyla birlikte ele alınmıştır. En yüce mutluluğa ulaşmak, insanı yetkin kılacak davranış ve bilgileri yani erdemleri karakterine işlemekle mümkündür. Her insanın kaçınılmaz olarak mutluluğu istediğini kabul eden islam filozofları mutluluğu, "gaye, iyi ve yetkinlik" bağlamıyla ortaya koymuştur. Buna göre insanın birden fazla yöneldiği gaye, iyi ve yetkinlik söz konusu olabileceğinden gerçek mutluluk "en son gaye, en yüksek iyi ve en yüksek insani yetkinlik"tir. İslam flozofları mutluluğun gelir ve maddi ilerlemeye paralel bir doyumdan uzak olduğunu belirtmektedir (Bircan, 2001). Fromm (1993) mutluluğu 'yanıltıcı'lığı sebebiyle zevk kavramindan uzak değerlendirmiştir. Kendi benlik bütünlügünü muhafaza ederek potansiyelini geliştirmek mutluluk için önemlidir. Ayrıca mutluluk erdemde bir ölçüttür. Acının ve kederin yokluğu mantıksal bir çıarımla mutluluğu meydana çıkarmamaktadır. Bunlar yaşamın bir parçası olmanın yanında bireysel işlerliğin de göstergesidir. Acıdan kaçmak yaşamla arasındaki bütün bağları koparmakla mümkün olabilir ki bu da bireyde ruhsal çöküntüye sebep olur.

Batı kültürlerinde mutluluk tasviri bireysel yanlara (bireyselciliğe) vurgu yapmaktadır. Fakat doğu toplumları, mutluluktan bahsederken bireysellikten daha çok toplumsal değerleri de içine alan değerlendirmelere yer vermektedir. Örneğin; aile, gelenek ve kültür bağlamlarıyla açıklanmaktadır. Birey toplumsal rol ve sorumluluklarını yerine getirdiği ölçüde mutlulukla yan yana değerlendirilir ( Özdemir ve Koruklu, 2011). Diener ve Diener, (1996) mutluluğu, bireyin kendi yaşamını değerlendirdiğinde 
bilişsel olarak memnuniyet içeren çıkarımlara varması ve duygusal anlamda güzel hisler bildirmesini ifade ettiğini belirtmektedir. Bunun yanında mutluluğun, "olumlu duygular, olumsuz duygular ve yaşam doyumu " şeklinde üç bileşeni vardır. Olumlu duygular neşe, ümit ve heyecan gibi duyguları, olumsuz duygular suçluluk hissi, öfke, gerginlik ve nefret duyguların, yaşam doyumu ise uzun vadeli yaşam memnuniyeti hislerini barındırmaktadır (Myers ve Deiner 1995).

Değerlerin olmadığı var sayımıyla Maslow (1968), değer yoksunluğunu, hayattan zevk almama noktasında bireysel, doğrudan bir etkiyle de toplumsal eylemlere, çerçeve oluşturacak ilkelerin yokluğunda, ümitsizliğin ve gelecek endişesinin hâkim olduğu bir hayatın varlığı ile marazlı bir ruh haline sahip olmak olarak tasvir etmektedir. Dolayısıyla bu noktada sahip olunan değerlerin, psikolojik iyi oluşla ilişkisinin önemli olduğu konusu ortaya çıkmaktadır.

Psikolojik iyi oluş, her yönüyle kendini kabulü, çevresindeki insanlarla olumlu ilişkiler kurabilme yetisini, yaşamının anlam ve amaçlar içermesini, kişisel gelişime açıklığı, özerklik/bağımsızlık ve çevresel hâkimiyet yeteneğini gerektirir (Ryff, 1989). Kederin yokluğu psikolojik iyi oluşu tanımlamada yeterli değildir, bunun yanında doyum ve içsel değerlilik gereklidir. Psikolojik iyilik aynı zamanda manevi ihtiyacın beslenmesi, özerklik, bağımsızlık, affedebilme, insanlarla yakın ilişkiler kurabilme ve üretkenlik gibi olumlu özellikleri ifade eder (Güleç, 2016). Özen (2010) psikolojik iyi oluşun bireyin kendi sorumluluğunda olduğunu savunmaktadır. İnsanın yaşamın bütün sorumluluklarını alabilmesi, tercihlerinin sonuçlarını kabul etmesinin psikolojik iyi oluşu konusunda önemli bir nokta olduğunu vurgulamaktadır. Ayrıca kuram olarak psikolojik iyi oluş, pozitif işlevleri olan bireyin özelliklerini incelemektedir.

Görüldüğü gibi değerler ve psikolojik iyi oluş, genelde ve özelde, amaç, inanç ve ihtiyaç barındırması bakımından ayrıca bilişsel, duyuşsal ve davranışsal boyutlara sahip olması yönüyle ortak bir zeminde buluşmaktadır. Özdemir ve Koruklu (2011), bireyin mutluluğunun amaç ve anlam gereksinimi sebebiyle değerlerle bağlamı olduğunun altını çizmektedir. Bu değerlendirme insana dair her türlü biliş, duyuş ve davranışın kaynağını bireyde anlam ifade eden değerlerden aldığı yargısını desteklemektedir. 
Bir toplumda hiyerarşik olarak üstün tutulan değer o topluma şekil verir. Kimi toplumun geleneksel, kiminin dini değerleri ile birlikte anılması, baskın olan değerin sosyal yaşama olan etkisinin yansımasıdır. (Güngör, 1998). Değerlerin ele alınıp incelenmesinin altında yatan temel sebep toplumun değişimidir (Demircioğlu ve Tokdemir, 2008). Değerlerdeki dinamik yapının kaçınılmazlığı (Vurgun ve Öztop, 2011) düşünüldüğünde, toplumu oluşturan fertlerin özellikle de kimlik kazanımı, bunalımlar, ani değişiklikler ve kararsızlıklar çağı olarak isimlendirilen, (Yavuzer, Meşeci, Demir ve Setrelin, 2005) gençlik dönemi içerisinde olan bireylerin, sahip olduğu değerlerin psikolojik iyi oluş ve mutluluklarını ne yönde etkilediği önemlidir. Mutluluk insanın ulaşmak istediği bir hedef ise bu hedef, bireye kendisine ulaştı̆̆ında anlamını kaybetmeyecek gerçek mutluluğa nasıl ulaşabileceğinin yol ve yöntemini sağlamaktadır. Çünkü hedef, kendisine nasıl ulaşılacağının araçlarını da belirlemiş olur (Bircan, 2001). Son zamanlarda artan bireysellik ve özgürlük vurgularının içine sıkıştırılmaya çalışılan bireyin toplumsal dönüşümde, hazzı önceleyen bir yaşam tarzı benimsemesine sebep olmuştur (T.C. Başbakanlık Aile ve Sosyal Araştırmalar Genel Müdürlüğü, 2010). Bu bağlamda, bireylerin değer önceliklerinin neler olduğu, hangi değerlerin ruh sağlı̆ ını öncelediği, psikolojik iyi oluş ve mutlulukla ilişkili olan değerlerin resmi ve sosyal sistemlere aktarımının yoğunluğu, yolu ve yöntemleri üzerinde durulması, teorik çalışmaların yanında uygulama çalışmalarının da artırılması konusunu gündeme getirmektedir. Bu önemle, çalışmamada değerlerin, psikolojik iyi oluş ve mutluluk üzerinde doğrudan ve dolaylı ilişkisinin ortaya çıkarılması hedeflenmiştir.

\section{Yöntem}

\section{Araştırmanın Modeli}

Nicel araştırma paradigmasına sahip bu çalışmada, üniversite öğrencilerinin sahip oldukları değerler, psikolojik iyi oluşları ve mutluluk değişkenleri aralarındaki ilişkilerin yapısal eşitlik modeli ile sınanması amaçlanmıştır. Bu amaç doğrultusunda araştırma, genel tarama modelinin bir alt türü olan ilişkisel tarama modeline göre gerçekleştirilmiştir. 


\section{Çalışma Evreni ve Grubu}

Araştırmanın çalışma grubunu İstanbul ilinde farklı bölümlerde ve farklı sinıflarda öğrenim gören 747 üniversite öğrencileri oluşmaktadır. Yaşları 18 ile 20 arasında değişen katılımcıların 280'i (\%37.5) 21-25 yaş aralığında, $418^{\prime} 1$ (\%56.0) 26-30 yaş aralığında, 28'i (\% 3.7) si, 21'i ise 31 ve üstü (\%2.8) yaş aralığındadır. Ayrıca katılımcıların 498'i (\%66.7) kadın 249”u (\%33.3) erkek öğrencilerden oluşmaktadır.

\section{Veri Toplamada Kullanılan Ölçme Araçları}

Değerler Ölçeği (DÖ):Dilmaç, Arıcak ve Cesur (2014) tarafından geliştirilen değerler ölçeği, değer ifadelerinin kişinin yaşamındaki anlam ve önemine göre duygu ve düşüncelerini en iyi yansıttığını düşündüğü değer ifadelerini puanlamaya dayanmaktadır. Ölçek 39 değer ifadesi ve 9 alt boyuttan oluşmaktadır. Bunlar; "Toplumsal Değerler (Social Values)", "Kariyer Değerleri (CareerValues)", "Entellektüel Değerler (IntellectualValues)", "Maneviyat (SpritualValues)", "Materyalistik Değerler (MaterialisticValues)", "İnsan Onuru (Honor of Humanity)", "Romantik Değerler (RomanticValues)”, “Özgürlük (Freedom)” ve "Fütüvvet (Futuwwat/munificience ve courage)" olarak isimlendirilmiştir. Ölçek likert tipi olup 0'dan 9'a kadar değer almaktadır. Ölçekten alınan puanın düşmesi ve s1fıra yaklaşması o değerin kişinin yaşamında çok önemli yer tutmadığını; puanın yükselmesi ve dokuza yaklaşması, o değerin kişinin hayatında çok önemli ve vazgeçilmez olduğunu göstermektedir. Öncelikle tüm değer ifadeleri için temel bileşenler analizi bağlamında açımlayıcı faktör analizi yapılmıştır. Kaiser-Meyer-Olkin örneklem uygunluğu değeri 926 ve BartlettSphericity Testi yaklaşık Ki-Kare değeri 14543.11 ( $\mathrm{p}<.001$ ) olarak bulunmuştur. Bileşen matrisi ve Varimax yöntemiyle gerçekleştirilen döndürme bileşen matrisi incelendiğinde tüm değerlerin toplam varyansın \%65.37'sini açılayan 13 faktör altında toplandığı görülmüştür. Ortak varyansların "zaman" dışında (.431) tamamının. 50'nin üzerinde olduğu tespit edilmiştir. Bununla birlikte döndürülmüş bileşen matrisinde yer alan 14 değerin aynı anda birden fazla faktör altında. 10'dan daha düşük bir farkla. 32 ve üzeri yük değerine sahip olduğu ya da bir faktör altında tek başına kaldığı görülmüştür (Aile, Zaman ve Kişisel İç Bütünlük tek kalan 
değerlerdir). Bu nedenle bu 14 değer çıkartılarak aynı koşullar altında benzer nedenlerle açımlayıc faktör analizi iki kere daha tekrarlanmıştır. Üçüncü faktör analizinde beş değer ve dördüncü faktör analizinde iki değer daha çıkartılmış, geriye kalan 39 değerin sorunsuz bir şekilde toplam varyansın \%64.74'ünü açılayacak şekilde dokuz faktör altında toplandığ 1 görülmüştür. Son faktör analizinde Kaiser-Meyer-Olkin örneklem uygunluğu değeri. 910 ve BartlettSphericity Testi yaklaşık Ki-Kare değeri 9133.26 (p<.001) olarak bulunmuştur. Adalet/Hakkaniyet (.466) dışındaki tüm değerlerin ortak varyansının. 50 ile. 80 arasında değişmekte olduğu görülmüştür. Değerler Ölçeğinin faktörler bazında Cronbach alfa iç tutarlılık güvenirlik katsayıları da hesaplanmıştır. Analiz sonucunda "Toplumsal Değerler" için .90, "Kariyer Değerleri" için .80, "Entellektüel Değerler" için .78, "Maneviyat"için .81, "Materyalistik Değerler" için .78, "İnsan Onuru" için .61, "Romantik Değerler"için .66, "Özgürlük" için .65 ve "Fütüvvet" için de .63 olarak hesaplanmıştır. Sonuç olarak, Değerler Ölçeği'nin ilk psikometrik bulguları, ölçeğin geçerli ve güvenilir bir ölçme aracı olduğu yönündedir.

Psikolojik İyi Oluş Ölçeği (PİÖ):Psikolojik İyi Oluş Ölçeği Diener, Scollon ve Lucas (2009) ve Diener, WirtzTov Kim-Prieto, Choi, Oishi ve Biswas(2010) tarafından mevcut iyi oluş ölçümlerini tamamlayıcı, sosyopsikolojik iyi oluşu ölçmek için geliştirilmiştir. Ölçeğin Türkçeye uyarlama çalışması Telef $(2011 ; 2013)$ tarafından yapılmıştır. Açımlayıcı faktör analizi sonucunda toplam açıklanan varyansın \%42 olduğu saptanmıştır. Ölçek maddelerinin faktör yükleri .54 ile .76 arasında hesaplanmıştır. Doğrulayıcı faktör analizinde uyum indeksi değerleri RMSEA $=0.08$, $\mathrm{SRMR}=0.04, \mathrm{GFI}=0.96, \mathrm{NFI}=0.94, \mathrm{RFI}=0.92, \mathrm{CFI}=0.95$ ve $\mathrm{IFI}=0.95$ olarak bulunmuştur. Psikolojik İyi Oluş Ölçeği Psikolojik İyi Oluş Ölçeklerinin alt boyutlarından özerklikle .30, çevresel hakimiyetle .53, bireysel gelişimle .29, diğerleri ile olumlu ilişki .41, yaşam amaçlarıla .38, öz-kabulle .56 ve toplam psikolojik iyi oluş ile .56 düzeyde ilişki bulunmuştur. Ayrıca İhtiyaç Doyum Ölçeğinin alt boyutlarından özerklikle .30, yeterlikle .69, ilişkili olmayla .57 ve toplam ihtiyaç doyumu ile .73 düzeyde ilişki saptanmıştır. Ölçeğin güvenirlik çalışmasında elde edilen Cronbach alfa iç tutar- 
lılık katsayısı .80 olarak hesaplanmıştır. Test tekrar test sonucuna göre ölçeğin birinci ve ikinci uygulama arasında yüksek düzeyde, pozitif ve anlamlı ilişki olduğu görülmüştür $(r=0.86, p<.001)$. Psikolojik İyi oluş ölçeğinin madde toplam korelasyonlarının .41 ile .63 arasında değişiklik gösterdiği ve t-değerlerinin anlamlı olduğu saptanmıştır $(p<.001)$ (Diener ve vd, 2010).

Oxford Mutluluk Ölçeği Kısa Formu (OMÖ-K):Oxford Mutluluk Ölçeği Kısa Formu-OMÖ-K (Hills ve Argyle, 2002) mutluluk düzeyini değerlendirebilmek amacıyla geliştirilmiş 8 maddelik bir ölçektir. Bu çalışmada OMÖ-K Türkçe'ye (Doğan ve Akıncı-Çötok, 2011) çevrilmiş ve psikometrik özellikleri incelenmiştir. Çalışma, Sakarya Üniversitesi'nde öğrenimlerine devam etmekte olan 532 üniversite öğrencisi ile yürütülmüştür. Veri toplama araçları olarak OMÖ-K ile birlikte Yaşam Doyumu Ölçeği, Yaşam Yönelim Testi ve Zung Depresyon Ölçeği kullanılmıştır. OMÖ-K'nun psikometrik özellikleri madde analizi, açımlayıcı ve doğrulayıcı faktör analizi, benzer ölçek geçerliği, iç tutarlık ve test tekrar test yöntemleriyle incelenmiştir. Faktör analizi sonuçları ölçeğin tek faktörlü bir yapıya sahip olduğunu ortaya koymuştur. Benzer ölçek geçerliği kapsamında OMÖ-K ile Yaşam Doyumu Ölçeği ve Yaşam Yönelimi Testi arasında pozitif yönde anlamlı ilişkiler bulunmuştur. OMÖ-K ile Zung Depresyon Ölçeği arasinda ise negatif yönde manidar ilişki bulunmuştur. Ölçeğin iç tutarlık ve test tekrar test güvenirlik katsayıları sırasıyla .74 ve .85 olarak saptanmıştır. Sonuç olarak OMÖ-K' nun Türk üniversite öğrencilerinin mutluluğunu ölçmede kullanılabilecek geçerli ve güvenilir bir ölçme aracı olduğu söylenebilir.

\section{Verilerin Toplanması ve Analizi}

Verilerin toplanması amaciyla, uygun örnekleme yöntemi ile tespit edilen katılımcılara Değerler Ölçeği, Psikolojik İyi Oluş ölçeği ve Oxford Mutluluk Ölçeği Kısa Formu uygulanmıştır. Araştırmada, üniversite öğrencilerinin sahip oldukları değerler, psikolojik iyi oluşları ve mutluluk değiş̧kenleri aralarındaki ilişkilerin yapısal eşitlik modeli ile sınanması amacıyla yapısal eşitlik modellemesi analizi yapılmıştır. Yapısal eşitlik modellemesi kuramsal bir modeli test etmek için gözlenen ve gizil değişkenler 
arasındaki nedensel ve karşılıklı ilişkileri ortaya koyan istatistiksel bir yaklaşımdır (Schumacker ve Lomax, 2004). Yapısal eşitlik modellemesi analizi AMOS 19 Programı ile gerçekleştirilmiştir.

\section{Bulgular}

Elde edilen son modelde $\left(\mathrm{X}^{2}=519,418, \mathrm{df}=229, \mathrm{p}<.001\right)$ dokuz exogenus, değerler (toplumsal, kariyer, entelektüel, maneviyat, materyalistlik, insan onuru, romantik, özgürlük ve fütüvvet) iki endogenous (psikolojik iyi oluş ve mutluluk) veri yer almaktadır. Modelde gösterilen yolların her biri istatistiksel olarak anlamlı bulunmuştur. The Bentler-Bonettnormed fit index (NFI), TheTucker-Lewiscoefficient fit index (TLI) ve diğer uyum indeksleri modelin oldukça iyi uyumlu olduğunu göstermiştir (Tablo-). Modelde yer alan endogenous verileri arasındaki iki yönlü korelasyonların her biri yüksek değerlere sahiptir ve istatistiksel olarak anlamlıdır. Bu durum, çalışmada kullanılan değerler ölçeğinin alt boyutlarının sahip olduğu korelasyon değerlerinden de etkilenmektedir.

Tablo 1: Yapısal Eşitlik Modelinin Uyumuna İlişkin İstatistiksel Değerler

\begin{tabular}{lccc}
\hline Ölçüm & İyi Uyum & Kabul Edilebilir Uyum & $\begin{array}{c}\text { Modelin Uyum İndeksi } \\
\text { Değerleri }\end{array}$ \\
\hline (X2/sd) & $\leq 3$ & $\leq 4-5$ & 2.26 \\
RMSEA & $\leq 0.05$ & $0.06-0.08$ & 0.04 \\
SRMR & $\leq 0.05$ & $0.06-0.08$ & 0.03 \\
NFI & $\geq 0.95$ & $0.94-0.90$ & 0.92 \\
CFI & $\geq 0.97$ & $\geq 0.95$ & 0.96 \\
GFI & $\geq 0.90$ & $0.89-0.85$ & 0.94 \\
AGFI & $\geq 0.90$ & $0.89-0.85$ & 0.93 \\
TLI & $\geq 0.95$ & $0.94-0.90$ & 0.94 \\
\hline
\end{tabular}

Tablo 1'de yer alan uyum değerleri incelendiğinde, $\mathrm{X}^{2} / \mathrm{sd}=2.26$, RMSEA $=0.04$, SRMR $=0.030, \mathrm{NFI}=0.92, \mathrm{CFI}=0.96, \mathrm{GFI}=0.94, \mathrm{AGFI}=0.93$ ve TLI $=0.94$, olarak bulunmuştur. Genel olarak, modelin istenen düzeyde uyum değerlerine sahip olduğu anlaşılmaktadır (Bollen, 1989; Browne ve Cudeck, 1993; Byrne, 2010; Hu ve Bentler, 1999; Kline, 2011; Tanaka ve Huba, 1985). Test edilen tek faktörlü model Şekil 3'te gösterilmiştir. Modelde gösterilen tüm yollar 0.01 ve 0.05 düzeyinde anlamlıdır. 


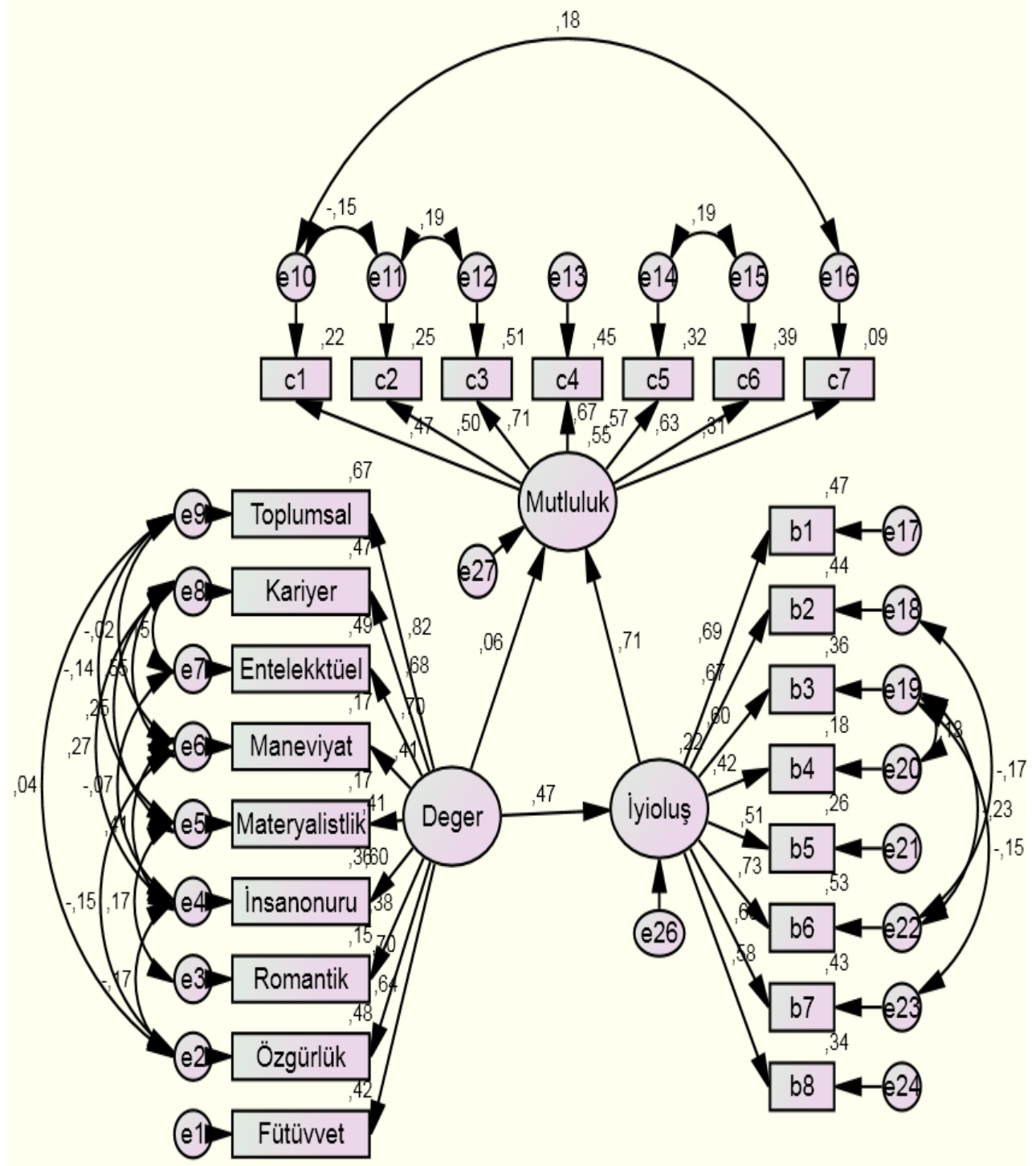

Şekil 1: Modele İlişkin Yol Analizi 
Üniversite Öğrencilerinin Sahip Olduğu Değerler, Psikolojik İyi Oluş ve Mutluluk Düzeyleri Arasındaki Yordayııı İlişkiler

Tablo 2: Üniversite Öğrencilerin Sahip Olduğu Değerler, Mutluluk Ve Psikolojik İyi Oluş Düzeyleri Asındaki Yordayıcı İlişkilere Yönelik Model

\begin{tabular}{|c|c|c|c|c|c|c|}
\hline $\begin{array}{l}\text { Yorda- } \\
\text { y1c1 } \\
\text { Değiş- } \\
\text { ken } \\
\end{array}$ & $\begin{array}{l}\text { Bağımlı } \\
\text { Değişken }\end{array}$ & $\begin{array}{l}\text { Toplam } \\
\text { Etki }\end{array}$ & $\begin{array}{l}\text { Doğrudan } \\
\text { Etki }\end{array}$ & $\begin{array}{l}\text { Dolaylı } \\
\text { Etki }\end{array}$ & $\begin{array}{l}\text { Standart } \\
\text { Hata }\end{array}$ & $\begin{array}{l}\text { Kritik } \\
\text { Değer }\end{array}$ \\
\hline Değerler & Mutluluk & 0.39 & 0.06 & 0.33 & 0.01 & $1.38^{* *}$ \\
\hline Değerler & $\begin{array}{l}\text { Psikolojik } \\
\text { İyi Oluş }\end{array}$ & 0.47 & 0.47 & 0 & 0.02 & $9.75^{*}$ \\
\hline $\begin{array}{l}\text { Psikolo- } \\
\text { jik İyi } \\
\text { Oluş }\end{array}$ & Mutluluk & 0.71 & 0.71 & 0 & 0.04 & $9.51^{*}$ \\
\hline
\end{tabular}

${ }^{a}$ Toplam etki $=$ Doğrudan etki + Dolayl et $k i,{ }^{*} p<0.01,{ }^{* *} p<0.05$.

Tablo incelendiğinde, mutluluğu etkileyen önemli bağımsız değişkenlerden birinin $(t=9.51, p<0.01)$ psikolojik iyi oluş değişkeni olduğu görülmektedir. Bu faktöre ilişkin bağlantı katsayı değeri $\beta=0.71$ olarak bulunmuştur. Üniversite öğrencilerin psikolojik iyi oluşları ile mutluluk düzeyleri arasındaki yordayıcı ilişkiler incelendiğinde, pozitif yönlü doğrusal bir ilişki olduğu görülmektedir. Başka bir ifadeyle elde edilen bulgular, üniversite öğrencilerin, psikolojik iyi oluş düzeylerinin artmasıyla mutluluk düzeylerinde artış olacağını ortaya koymaktadır.

Modelde psikolojik iyi oluşu etkileyen en önemli değişkenin ( $t=9.75$, $p<0.01)$ değerler olduğu görülmektedir. Bu faktöre ilişkin bağlantı katsayı değeri $\beta=0.47$ olarak belirlenmiştir. Üniversite öğrencilerin sahip olduğu değerler ile psikolojik iyi oluş arasındaki yordayıcı ilişkiler incelendiğinde, pozitif yönlü doğrusal bir ilişki olduğu görülmektedir. Başka bir ifadeyle elde edilen bulgular, üniversite öğrencilerin sahip oldukları değerler arttıkça psikolojik iyi oluş düzeylerinin de artacağını ortaya koymaktadır.

Ayrıca test edilen modelde, üniversite öğrencilerinin mutluluk düzeylerini etkileyen ikinci önemli bağımsız değişkenin $(t=1.38, p<0.05)$ değer değişkeni olduğu görülmektedir. Bu faktöre ilişkin bağlantı katsayı değeri $\beta=0.06$ olarak belirlenmiştir. Üniversite öğrencilerin sahip oldukları değerler ile mutluluk düzeyleri arasındaki yordayıcı ilişkileri incelendiğinde, pozitif yönlü doğrusal bir ilişki olduğu görülmektedir. Başka bir 
ifadeyle elde edilen bulgular, üniversite öğrencilerin sahip oldukları değerlerin artmasıyla mutluluk düzeylerinde artma olacağını ortaya koymaktadir.

\section{Tartışma}

Çalışmanın bu bölümünde çalışma grubunu oluşturan üniversite öğrencilerinin, sahip olduğu değerlerin, psikolojik iyi oluş ve mutluluk arasındaki ilişkinin incelenmesi sonucunda elde edilen bulgular tartışılarak yorumlanmıştır.

Üniversite öğrencilerinin sahip olduğu değerler ile psikolojik iyi oluş arasındaki yordayıcı ilişkiler incelendiğinde, pozitif yönlü doğrusal bir ilişki olduğu görülmektedir. Başka bir ifadeyle elde edilen bulgular, üniversite öğrencilerinin sahip oldukları değerler arttıkça psikolojik iyi oluş düzeylerinin de artacağını ortaya koymaktadır. Yapılan benzer çalışmalar incelendiğinde, Telef, Uzman ve Ergün'ün (2013) öğretmen adaylarının psikolojik iyi oluşları ve sahip olduğu değerlerden başarı, hazcılık, özyönelim, evrenselcilik, iyilikseverlik, uyma ve güvenlik arasında pozitif yönde anlamlı ilişkiler olduğu sonucuna ulaşılmıştır. Özellikle özaşkınlık değer boyutunun psikolojik iyi oluşu anlamlı düzeyde yordadığı görülmüştür. Joshanloo ve Ghaedi (2009), İran'da 200 üniversite öğrencisiyle gerçekleştirdiği çalışmada değerlerin iyi oluşun hedonik boyutundan ziyade ödomonik boyutuyla, pozitif yönde ilişkili olduğunu göstermiştir.

Çalışmanın sonucunu dolaylı olarak destekleyen bir diğer çalışma, ahlaki değerlere (ahlaki olgunluk) sahip olmanın psikolojik iyi oluşu ne yönde yordadığını ortaya koymak için yapılmıştır. Farhan, Dasti ve Khan (2015), tarafından üniversite öğrencilerine yönelik gerçekleştirilen araştırmaya göre ahlaki olgunluğu işaret eden ahlaki değerlere sahip olan bireyler yüksek derecede psikolojik iyi oluş bildirmiştir. Bunun yanında sevgi şefkat ve minnettarlık değerlerinin hem ruh sağlığına hem de fiziksel sağlığa olumlu etkilerinin olduğunu McCraty ve Childre (2002) çalışmalariyla ortaya koymuştur.

Yaşamın güçlükleriyle başa çıkmada bireye yardımcı olan inanç, aynı zamanda bireyin hayatı anlamlandırmasına da yardımcı olmaktadır (Tuzgöl- Dost, 2007). Dini inancın (Balcl, 2011; Tuzgöl- Dost, 2007) ve dini yönelimin (Göcen, 2013) ibadet etmenin (Kaya ve Küçük, 2017) psikolojik 
iyi oluşla ve yaşamı anlamlandırmayla doğrudan ilişkili olduğu sonucuna ulaşmış çalışmalar bulunmaktadır. Bunun yanında psikolojik iyi oluşla şükretmenin çeşitli boyutları (mukayeseli şükür, memnuniyete yönelik şükür, aileye yönelik şükür, ibadete yönelik şükür) arasında anlamlı bir ilişki olduğunu Göcen (2012), çalışmasıyla ortaya koyulmuştur.

Lun ve Bond (2013), 2005-2008 y1lları arasında 57 ülkeden 82.982 katılımcıdan oluşan örneklemiyle gerçekleştirdiği araştırmada maneviyat, dindarlık ve yaşam memnuniyeti arasındaki ilişkinin pozitif yönde olduğu bilgisine ulaşmıştır. Sonuç itibariyle çalışma, dindarlık ve maneviyatın yaşam memnuniyeti, iyi oluş ve mutluluk arasında pozitif yönde yordayıc ilişkiler olduğunu tespit etmiştir. Sabır değeri, yaşamın zorluklarını sakinlikle karşılamada önemli bir karakter gücüdür. (Schnitcer, 2010). Bu fikrin doğruluğunu araştırmak amacıyla Schnitcer (2010), gerçekleştirdiği çalışma sonucunda sabrın strese bağlı yaşanan olumsuzluklarda tampon görevi olduğunu ortaya koymuştur. Ayrıca sabrın iyi oluşun hem hedonik hem de eudaimonik boyutlarıyla pozitif yönlü olumlu ilişkisinin olduğu belirtilmiştir. Dolayısıyla manevi değerler içinde yer alan şükretmek, ibadet etmek ve zor zamanlarında inancına sığınıp güç almanın bireylerin iyi oluşunu olumlu yönde etkilediği sonucu ortaya çıkmaktadır. Bu sonuçlar da manevi değerler ve psikolojik iyi oluş arasında pozitif bir ilişki olduğunu ortaya koyması bakımından çalışmanın sonucunu destekler niteliktedir.

Literatürde öznel iyi oluş ve psikolojik iyi oluş ayrımı tartışmasına Diener, Wirtz, Toy, Kim-Prieto, Choi ve Biswas- Diener'ın (2010) getirdiği açıklama, öznel iyi oluşun bireyin kendini değerlendirmesi sonucunda vardığı yargıyı, psikolojik iyi oluşun ise bireyin bütün işlevlerini barındırdığı yönündedir. Bu amaçla geliştirmiş oldukları psikolojik iyi oluş ölçeği, olumlu duyguların yanında yaşamın anlam ve amaç içermesini, destekleyen ve takdir eden sosyal ilişkileri, yetenek ve ilgisiyle akışı deneyimleyeceği aktiviteleri, insanların iyiliğine katkı sağlayabilmeyi, yeterliliği, özkabulü, iyimserliği ve saygı görmeyi barındıran boyutlardan oluşmaktadır. Boyutlar incelendiğinde psikolojik iyi oluş ve değerlerin ortak değişkenler içerdiği görülmektedir. Belirtilen psikolojik iyi oluş boyutlarından hareketle Çetinkaya (2011), emekli bireylerin yaşam doyumunu etkileyen 
en önemli faktörlerin, sosyal destek ve öz-yeterlilik olduğunu ortaya koymuştur. Dilmaç, Deniz ve Yıldız (2011) öğretmen adaylarının sahip oldukları değerlerle psikolojik iyi oluş boyutlarından, benlik saygısı arasındaki ilişkiyi araştırmış ve söz konusu değişkenler arasında pozitif bir ilişkinin olduğunu ortaya koymuştur.

Materyalist değerlerin psikolojik iyi oluşla ilişkisini araştıran Tatlığlu (2014), üniversite öğrencilerinin aylık harcanan para miktarıyla psikolojik iyi oluş boyutları arasında anlamlı bir fark olmadığı sonucuna ulaşmıştır. Materyalist değerler konusunda başkalarının refahı için harcamanın bireysel harcamadan daha kalıcı bir mutluluk sağladığını ortaya koyan araştırmalar da mevcuttur (Dunn, Aknin ve Norton, 2008).

Çalışmanın bir diğer sonucu; üniversite öğrencilerinin sahip oldukları değerler ile mutluluk düzeyleri arasındaki ilişkidir. Değerler ve mutluluk arası yordayıcı ilişkiler incelendiğinde, aralarında pozitif yönlü doğrusal bir ilişki olduğu görülmektedir. Dolayısıyla elde edilen bulgular, üniversite öğrencilerinin sahip oldukları değerlerin artmasıyla mutluluk düzeylerinde de artış olacağını ortaya koymaktadır. Yapılan araştırmalar incelendiğinde Özdemir ve Koruklu'nun (2011) çalışma sonucuyla benzerlik gösterdiği görülmektedir. Üniversite öğrencilerine yönelik yapılan araştırma sonucuna göre mutluluğu en fazla yordayan değerler evrenselcilik ( insanı anlama, insana değer verme, hoşgörülü olma) ve iyilikseverlik olmuştur. Çalışmanın sonucunu destekleyen bir diğer araştırma Seki (2014) tarafından ergenler üzerinde yapılmıştır. Elde edilen sonuç yapılan çalışmanın sonucuyla aynı doğrultudadır. Buna göre sorumluluk dostlukarkadaşlık, saygı ve dürüstlük alt boyutları ile öznel iyi oluşun bütün alt boyutları arasında olumlu yönde anlamlı ilişki bulunmuştur.

Materyalist değerlerin mutluluğu nasıl etkilediğini ortaya koyan ulusal çalışmalara kıyasla uluslararası literatürde çok sayıda çalışmanın yer aldığ1 görülmektedir. Kasser ve Ahuvia (2002) Singapur'da yapmış olduğu araştırmada para ve imajı temsil eden değer yöneliminin üniversite öğrencilerinde anksiyete ve mutsuzluk belirtilerinin olduğu sonucunu ortaya koymuştur. Veenhoven ve Dumludağ (2015) ABD'nin 1973- 2003 yılları arasında kişi başına düşen gelir seviyesinde yüzde 60 oranında artışa rağmen mutluluk seviyesinde herhangi bir değişimin olmadığı bilgisini, materyalist değerlerin mutluluk üzerindeki etkisinin çok fazla olmadığına kanıt olarak göstermiştir. 
Mutluluk, bireyin kendi yaşamını değerlendirmesi anlamını içerir ve mutluluk bildiren birey yaşam kalitesini ortaya koymuş olur (Selim, 2008). Kaya ve Küçük (2017) ise mutluluğu "memnuniyet" çerçevesiyle değerlendirmenin yerinde olacağını savunmaktadır. Çünkü memnuniyet sadece içsel bir durumu değil aynı zamanda belli davranış kalıplarını da ortaya koymaktadır yorumuyla mutluluğu Aristoteles'in düşüncesini referans alarak değerlendirmektedir. Bu bağlamdan hareketle değerlerin içselleştirilip davranışlara dönüşmesinin mutlulukla olan ilişkisini de bir bakıma ortaya koyması anlamına gelmektedir. Dursun (2016) mutluk ve psikolojik iyi oluş konusunda önemli bir faktör olan yaşam doyumu ile değerler arasındaki ilişkinin pozitif yönlü ve anlamlı olduğu sonucuna ulaşmıştır. İşgör'ün (2017) merhamet değeri ve öznel iyi oluş arasındaki ilişkiyi belirlemeye yönelik yaptığı çalışma sonucunda üniversite öğrencilerinin sahip olduğu merhametle, öznel iyi oluşları arasında pozitif ve anlamlı bir ilişki bulmuştur.

Çalışmadan elde edilen son sonuç ise, mutluluğu etkileyen önemli bağımsız değişkenlerden birinin psikolojik iyi oluş değişkeni olduğudur. Üniversite öğrencilerinin psikolojik iyi oluşları ile mutluluk düzeyleri arasinda pozitif yönlü doğrusal bir ilişki olduğu görülmektedir. Yani elde edilen bulgular üniversite öğrencilerinin, psikolojik iyi oluş düzeylerinin artmasıyla mutluluk düzeylerinde artış olacağını ortaya koymaktadır. Konu ile ilgili yapılan araştırmalar incelendiğinde, psikolojik iyi oluşun mutlulukla olan ilişkisini ortaya koyan bir araştırmaya rastlanmamıştır. Mutluluğun daha çok demografik özelliklere (Cenkseven ve Akbaş, 2016; Morgan, Robinson ve Thompson, 2015; Akın ve Şentürk 2012; Ercan ve Eryılmaz, 2011), kişilik özelliklerine(DeNeve ve Cooper 1998; Demirci ve Ekşi, 2017), psikolojik ihtiyaçlara (Bozgeyikli, 2010), gelir düzeyine (Veenhoven ve Dumludağ, 2015) göre nasıl değiştiği tartışılmıştır. Eryılmaz ve Atak' in (2011), Psikolojik iyi oluşun boyutlarından olan "iyimserliğin" ve "öz-sayg1" nın ergenlerin öznel iyi oluşları üzerinde olumlu etkisinin olduğunu ortaya koyan çalışma da ulaşmış olduğumuz sonuçla aynı doğrultudadır. Benlik saygısının öznel iyi oluş için önemli bir faktör olduğunu Doğan ve Eryılmaz da (2014) ortaya koymuştur. 
Çalışmanın sonucuyla dolaylı olarak ilişkilendireceğimiz bir araştırmayı ortaya koyan Kuyumcu (2013), pozitif ve negatif duyguların, psikolojik iyi oluşu nasıl yordadığını araştırmıştır. Çalışmanın sonucunda pozitif duyguların psikolojik iyi oluş boyutlarından sadece diğerleri ile olumlu ilişkileri yordadığını negatif duyguların ise psikolojik iyi oluş boyutlarının (diğerleriyle olumlu ilişkiler, özerklik, çevre hâkimiyeti, kişisel gelişim, yaşam amacı ve kendini kabul) tamamını yordadığı bilgisine ulaşmıştır. Psikolojik iyi oluşun boyutlarından olan yaşamda amaçlarının olması ile literatürde mutluluk yerine kullanılan öznel iyi oluş arasında ilişkiyi inceleyen İlhan ve Özbay'ın (2010) elde ettiği en önemli sonuç; içsel amaçların öznel iyi oluşa olumlu katkı sağladığı, dışsal amaçların ise öznel iyi oluş üzerinde olumsuz bir etkiye neden olduğudur.

Elde edilen sonuçlar ve sonuçları doğrudan ve dolaylı destekleyen çalışmalar ışığında değerlerin özellikle geleceği şekillendirecek olan genç bireylerin mutluluk ve psikolojik iyi oluşlarıyla ilişkili olduğu sonucuna ulaşılmıştır. Bu bağlamdan hareketle değerlerin sosyal ve kurumsal yapılarda eğitimlerinin artırılmasının psikolojik iyi oluşa dolayısıyla toplumun ruh sağlığına olumlu katkısının olacağı yorumunun yolunu açmıştır. 
EXTENDED ABSTRACT

\title{
Predictive Relationships Between University Students' Values, Psychological Well-Being And Happiness Levels
}

\author{
* \\ Semra Bulut / Bülent Dilmaç \\ İstanbul Metropolitan Municipality / Necmettin Erbakan University
}

In order to know the human being, its nature, its existence and to see the potentials and the potentials of them, one, one, one, one, one, one, one, one. What is the reason that prevents a situation from activating or activating a situation? Where do you get the source of belief to which an action or inaction depends? Different alternatives apply. It should be considered in this respect. Because the individual's emotion, thought and behavior is in the dimension of a person (Dilmaç, Bozgeyikli and Pebbly, 2008). In the mental process, there is a belief that perceptions, emotions and emotions provide an emotion and satisfies it. (Güngör, 1998).Because they are beliefs that contain corrosion (Dilmaç, 2007).

Psychologically, values revealed the basis of the motivations that reveal the personality of the individual (Sağnak, 2004). When the relevant definitions of values are examined, it is seen that information and method usage on custom, pieces, beliefs, goals, principles, objects, people and ideas come to the fore (Keskin, 2016). For this reason, it is the investigation of the density of a science such as philosophy sociology and psychology (Bircan and Dilmaç, 2015).

In Islamic philosophy, values are explained in the context of virtues and discussed with the concept of happiness Islamic philosophers, who accept that every human being inevitably wants happiness, revealed happiness in the context of goal, good and competence. According to this view, real happiness is the last aim, the highest human competence (Bircan, 2001). 
Masters (1968), depiction of lack of value, the point of not enjoying life, the lack of principles for social action, the formation of framework, the depiction of hopelessness and the future of fear as having a bitter spirit of life. The value of the values, psychological well-being and criticism is important in the circumstances.

In a society, the hierarchically superior value gives shape to that society. Some of the society is traditional, some of them appear together with religious values, the dominant value of social life is the effect. (Güngör, 1998). The main reason behind the control is the change in life (Demircioğlu, Tokdemir, 2008). The inevitability of the dynamic structure in the values (Vurgun and Öztop, 2011), I thought, the details of the society of the population acquisition, crises, sudden cage and instability, named, (Yavuzer, Meşeci, Iron and Setrelin 2005) in the youth period of the individuals, What is not their happiness. In this context, the values of values, which values are valid and the transfer to social systems, the formation of values and conditions, the theoretical work is brought to the agenda and brings to the agenda. With this importance, the study is associated with values, psychological well-being and happiness.

It has a quantitative research paradigm, the aim of this course, models not associated with psychological well-being and happiness variables. In this model, it is performed according to the combined model, which is a sub-type of the general scanning model. 498 (66.7\%) women in different departments and class research in Istanbul won 249 (33.3\%) male 747 universities.

Your data, the values obtained with appropriate sampling methods, the Psychological Well-being Scale and the Oxford Happiness Scale Short Form were applied. Research, variables associated with university students' risks and equations. Structural equation modeling analysis was performed with AMOS 19 Program.

According to the results of the study, it was concluded that there is a positive directional relationship between the values of university students and psychological well-being. In other words, the findings suggest that the levels of psychological well-being will increase as the values of the university students increase. When the predictive relationships between values and happiness are examined, it is seen that there is a positive linear relationship between them. The last result obtained from the study is that 
one of the important independent variables affecting happiness is the psychological well-being variable. It is seen that there is a positive linear relationship between the psychological well-being and happiness levels of university students.

\section{Kaynakça/References}

Akın, H. B. ve Şentürk, E. (2012). Bireylerin mutluluk düzeylerinin ordinal lojistik regresyon analizi ile incelenmesi. Öneri Dergisi, 10(37), 183193.

Bircan, H. H. (2001). İslam felsefesinde mutluluk. İstanbul: İz Yayıncılık.

Bircan, H. H. ve Dilmaç, B. (Ed.). (2015). Değerler bilançosu. Konya: Çizgi Kitapevi.

Bolay, S. H. (2007). Değerlerimiz ve günlük hayat. Değerler Ĕğitimi Merkezi Dergisi, 1(1), 12-19.

Bozgeyikli, H.(2010) The relationship between high school students' psychological needs and human value perceptions. Procedia Social and Behavioral Sciences, 9, 1798-1804.

Bozgeyikli H., Derin S. ve Toprak, E. (2016). Üniversite ögrencilerinin mesleki deger algıları. International Journal of Contemporary EducationalStudies, 2(1), 139-156.

Cenkseven, F., ve Akbaş, T. (2016). Üniversite öğrencilerinde öznel ve psikolojik iyi olmanın yordayıcılarının incelenmesi. Türk Psikolojik Danışma ve Rehberlik Dergisi, 3(27).43-65.

Çetinkaya, E. (2011). Emekli bireylere yaşam doyumunun yordayıcıları olarak sosyal destek ve öz-yeterlilik. Yayımlanmamış Yüksek Lisans Tezi, Hacettepe Üniversitesi, Ankara.

Demirci, İ. ve Ekşi, F. (2017). Büyüklemeci narsisizmin iki farklı yüzü: Narsistik hayranlık ve rekabetin mutlulukla ilişkisi. Eğitim Bilimleri Dergisi, 46, 37-58.

Demircioğlu, İ. H. ve Tokdemir, M. A. (2008). Değerlerin oluşturulma sürecinde tarih eğitimi: Amaç, işlev ve içerik. Değerler Eğitimi Dergisi, 6(15), 69-88.

DeNeve, K. M.ve Cooper, H. (1998). The happy personality: A meta-analysis of 137 personality traits and subjective well-being. Psychological Bulletin, 124(2), 197-229. 
Diener, E. ve Diener, C. (1996). Most people are happy. Psychological Science, 7, 181-185.

Diener, E.,Lucas, R. E. ve Scollon, C. (2006). Beyond the hedonic treadmill: revising thea daptation theory of well-being. American Psychologist, 61, 305-314.

Diener, E.,Wirtz, D., Tov, W., Kim-Prieto, C., Choi, D. W., Oishi, S., ve Biswas-Diener, R. (2010). New well-being measures: Short scales to assess flourishing and positive and negative feelings. Social Indicators Research, 97(2), 143-156.

Dilmaç, B. (2007). Bir grup fen lisesi öğrencine verilen insani değerler eğitimin insani değerler ölçeği ile sınanması. Yayınlanmamış Doktora Tezi, Selçuk Üniversitesi, Konya.

Dilmaç, B., Arıcak, O. T. ve Cesur, S. (2014). A validity and reliability study on the development of the values scale in Turkey. Educational Sciences: TheoryvePractice, 14(5), 1661-1671.

Dilmaç, B.,Bozgeyikli, H., ve Çıkılı, Y. (2008). Öğretmen adaylarının değer algılarının farklı değişkenler açısından incelenmesi. Değerler Ĕ̆ $i-$ timi Dergisi, 6(16), 69-91.

Doğan, T. ve Akınc1-Çötok, N. (2011). Oxford mutluluk ölçeği kısa formunun Türkçe uyarlaması: geçerlik ve güvenirlik çalışması. Türk Psikolojik Danışma ve Rehberlik Dergisi, 4 (36), 165-172.

Doğan, T. ve Eryılmaz, A. (2014). Benlik saygısı ve öznel iyi oluş arasındaki ilişkilerin incelenmesi. Pamukkale Üniversitesi Ĕ̆itim Fakültesi Dergisi, 33(33), 107-117.

Dunn, E. W.,Aknin, L. B. ve Norton, M. I. (2008). Spending money on others promotes happiness. Science, 319(5870), 1687-1688.

Eryılmaz, A. ve Atak, H. (2014). Ergen öznel iyi oluşunun, öz saygi ve iyimserlik eğilimi ile ilişkisinin incelenmesi. Elektronik Sosyal Bilimler Dergisi, 10(37), 170-181.

Eryılmaz, A. ve Ercan, L. (2011). Öznel iyi oluşun cinsiyet, yaş grupları ve kişilik özellikleri açısından incelenmesi. Türk Psikolojik Danışma ve Rehberlik Dergisi, 4(36), 139-149.

Fichter, J. (1990). Sosyoloji nedir? (çev. N. Çelebi). Konya: Toplum Yay.

Farhan R, Dasti ve R, Khan (2015). MNS. Moral intelligence and psychological wellbeing in health care students. Journal of Education Research and BehavioralSciences, 4(5), 160-164. 
Göcen, G. (2013). Pozitif psikoloji düzleminde psikolojik iyi olma ve dini yönelim ilişkisi: Yetişkinler üzerine bir araştırma. Toplum Bilimleri Dergisi, 7 (13), 97-130.

Göcen, G. (2012), Şükür ile psikolojik iyi olma hali arasındaki ilişki üzerine bir alan araştırması. Yayımlanmamış Doktora Tezi, Ankara Üniversitesi, Ankara.

Güleç, C. (2016). Pozitif ruh sağhığı.(3. Baskı). Ankara: Arkadaş.

Güngör, E. (1998). Değerler Psikolojisi Üzerine Araştırmalar: Ahlâk Psikolojisi, Ahlâki Değerler Ve Ahlâki Gelişme: Profesörlük Tezi, İstanbul: Ötüken.

Hills, P. ve Argyle, M. (2002). The Oxford Happiness Questionnaire: a compact scale for the measurement of psychological well-being. Personality and individual differences, 33(7), 1073-1082.

İlhan, T. ve Özbay, Y. (2010). Her amaç sağlığa iyi gelmez: Yaşam amaçların ve psikolojik ihtiyaç doyumunun öznel iyi oluş üzerindeki yordayıcı rolü. Türk Psikolojik Danışma ve Rehberlik Dergisi. 34 (2), 109119.

İşgör, İ. Y. (2017). Merhametin öznel iyi oluş üzerindeki yordayıcı etkisinin incelenmesi. Gaziantep University Journal of Social Sciences, 16(2). 425-436.

Joshanloo, M., ve Ghaedi, G. (2009). Value priorities as predictors of hedonic and eudaimonic aspects of well-being. Personality and IndividualDifferences, 47(4), 294-298.

Kapkın, B., Çalışkan, Z. ve Sağlam, M. (2018). Türkiye'de 1999-2017 yılları arasında değerler eğitimi alanında yapılmış lisansüstü çalışmalarin incelenmesi. Journal of Values Education, 16(35).

Karasar, N. (2015). Scientific method (28th ed.). Ankara: Nobel.

Kasser, T. ve Ahuvia, A. (2002). Materialistic values and well-being in business students. European Journal of Social Psychology, 32(1), 137146.

Kaya, M. ve Küçük, N. (2017). İbadetler ile hayatın anlamı ve psikolojik iyi olma arasındaki ilişkinin incelenmesi. Ondokuz Mayıs Üniversitesi İlahiyat Fakültesi Dergisi, (42), 17-43.

Keskin, Y. (2016). Değer ve norm ilişkisi. H. H. Bircan, B. Dilmaç(Ed). Değerler Bilançosu içinde (s. 125-150). Konya: Çizgi Kitabevi. 
Kuyumcu, B. (2013). Üniversite öğrencilerinin pozitif ve negatif duygu durumlarının psikolojik iyi oluşlarını yordama gücü. Kuramsal Ĕ̆itim Bilim Dergisi, 6(1), 62-76.

Lun, V. M. C. ve Bond, M. H. (2013). Examining therelation of religion and spirituality to subjective well-being across national cultures. Psychology of Religion and Spirituality, 5(4), 304- 315.

Maslow, A. (1968). İnsan olmanın psikolojisi (Çev: O. Gündüz). İstanbul: Kuraldişı.

McCraty, R. ve Childre, D. (2002). The grateful heart: The psychophysiology of appreciation. In: Emmons RA, McCullough ME, eds. (p:240-265), ThePsychology of Gratitude. New York: Oxford UniversityPress.

Morgan, J., Robinson, O. ve Thompson, T. (2015). Happiness and age in european adults: The moderating role of gross domestic product percapita. Psychology and Aging, 30(3), 544-551.

Myers, D. ve Deiner, E. (1995) Who is happy. AmPsycholSoc, 6(1) 10- 19.

Özdemir, Y. ve Koruklu, N. (2011). Investigating relatinship between values and happiness among university students. Yuzuncu Yal University, Journal of Faculty of Education, 8(1), 190-210.

Özen, Y. (2010). Kişisel sorumluluk bağlamında öznel ve psikolojik iyi oluş (sosyal psikolojik bir değerlendirme). Dicle Üniversitesi Sosyal Bilimler Enstitüsü Elektronik Dergisi, 4, 46-58.

Özensel, E. (2003). Sosyolojik bir olgu olarak değer. Değerler Ĕ̆gitimi Dergisi, 1 (3), 217-239.

Ryff, C. D. (1989). Happiness is everything, or is it? Explorations on themeaning of psychological well-being. Journal of Personality And Social Psychology, 57(6), 1069- 1081.

Sağnak, M. (2004). Kişi-örgüt değer uyumunu ölçme çalışmaları ve kullanılan yöntemlerin karşılaştırılması. Değerler Eğitimi Dergisi, 2(5), 101-124.

Schnitker, S. A. (2010). An Examination of patience and well-being (Doctoraldissertation), University of California, Davis.

Schumacker, R. E. ve Lomax, R. G. (2004). A beginner's guide to structural equation modelling. London: Lawrence ErlbaumAssociates. 
Schwartz, S. H. (2012). An overview of the schwartz theory of basic values. Online Readings in Psychology and Culture, 2(1). (Erişim Tarihi: 12.03.2018) http://scholarworks.gvsu.edu/cgi/viewcontent-.cgi?article $=1116$ vecontext $=$ orpc

Seki, T., ve Dilmaç, B. (2015). Ergenlerin sahip oldukları değerler ile öznel iyi oluş ve sosyal görünüş kaygı düzeyleri arasındaki yordayıcı ilişkiler: Bir model önerisi. Ĕ̆itim ve Bilim, 40(179) 57-67.

Selim, S. (2008). Türkiye'de bireysel mutluluk kaynağ1 olan değerler üzerine bir analiz: Multinomial logit model Journal of Çukurova University Institue of Social Sciences, 3(17), 345-358.

Tatlılıoğlu, K. (2015). Üniversite öğrencilerinin aylık gelir düzeyleri ile psikolojik iyi oluşları arasındaki ilişkinin incelenmesi (Bingöl üniversitesi örneği). Elektronik Sosyal Bilimler Dergisi, 14(55).1- 15.

T.C. Başbakanlık Aile ve Sosyal Araştırmalar Genel Müdürlüğü, (2010). Türkiye'de aile değerleri araştırması, Ed. Mustafa Turgut, Manas Medya Planlama Reklam Hizmetleri, Ankara

Telef, B. B. (2011). Psikolojik iyi oluş ölçeği (PİOO): Türkçeye uyarlama, geçerlik ve güvenirlik çalışması.11. Psikolojik Danışma ve Rehberlik Kongresi, 3-5 Ekim, Selçuk- İzmir.

Telef, B. B. (2013). Psikolojik iyi oluş ölçeği (PİO): Türkçeye uyarlama, geçerlik ve güvenirlik çalışması. Hacettepe Eğitim Fakültesi Dergisi, 28(3), 374-384.

Telef, B.B., Uzman, E. ve Ergün, E. (2013). Öğretmen adaylarında psikolojik iyi oluş ve değerler arasındaki ilişkinin incelenmesi. TurkishStudies- International PeriodicalForTheLanguages, Literature and History of TurkishorTurkic, 8 (12), 1297-1307.

Tuzgöl D. M. (2007). Üniversite öğrencilerinin yaşam doyumunun bazı değişkenlere göre incelenmesi. Pamukkale Üniversitesi Eğitim Fakültesi Dergisi, 22(22), 132-143.

Veenhoven, R. ve Dumludağ, D. (2015). İktisat ve mutluluk. İktisat ve Toplum Dergisi, 58, 46-51.

Vurgun, L. ve Öztop, S. (2011). Yönetim ve örgüt kültüründe değerlerin önemi. Süleyman Demirel Üniversitesi İktisadi ve İdari Bilimler Fakültesi Dergisi, 16(3). 217- 230. 
Yavuzer, H. Meşeci, F., Demir, İ. ve Sertelin, Ç., (2005). Günümüz üniversite gençliğinin sorunları. Hasan Ali Yücel Eğitim Fakültesi Dergisi, 1, 79-91.

Yıldız, M., Dilmaç, B. ve Deniz, M. E. (2013). Öğretmen adaylarının sahip oldukları değerler ile benlik saygıları arasındaki ilişkinin incelenmesi. İlköğretim Online, 12(3) 740-748.

\section{Kaynakça Bilgisi / Citation Information}

Bulut, S. ve Dilmaç, B. (2018). Üniversite öğrencilerinin sahip olduğu değerler, psikolojik iyi oluş ve mutluluk düzeyleri arasındaki yordayıcı ilişkiler. OPUS-Uluslararası Toplum Araştırmaları Dergisi, 9(16), 349-374. DOI: $10.26466 /$ opus. 472450 